\title{
MEMBANGUN KARAKTER BANGSA MELALUI PENGUATAN KETERAMPILAN BERPIKIR HISTORIS DALAM PEMBELAJARAN SEJARAH
}

\author{
Imbar Desi Mutri Yanti \\ NIM 1810111120020 \\ Program Studi Pendidikan Sejarah Fakultas Keguruan dan Ilmu Pendidikan \\ Universitas Lambung Mangkurat \\ Banjarmasin
}

\begin{abstract}
Abstrak
Artikel ini membahas mengenai membangun karakter bangsa melalui penguatan keterampilan berpikir historis dalam pembelajaran sejarah. Sejarah sebagai sebuah mata pelajaran yang diajarkan di sekolah memiliki posisi yang sangat strategis dalam pelaksanaan pendidikan karakter. Terlebih lagi melihat dari hakikat pembelajaran sejarah itu sendiri adalah mengajarkan masa lalu kepada siswa untuk menjalani masa kini dan melihat masa depan. Begitu visionernya hakikat pembelajaran sejarah yang mengandung nilai-nilai masa lampau yang sejatinya merupakan cerminan nilai dari leluhur bangsa pendahulu. Sehingga dalam memahami setiap nilai dan makna dari peristiwa sejarah tersebut diperlukan sebuah keterampilan spesialis, yaitu berpikir historis (historical thinking). Keterampilan berpikir historis terbentuk tidak lepas dari peran guru sejarah dalam pembelajaran di sekolah. Bahkan berpikir historis ini sudah menjadi bahasan yang panjang dalam pembelajaran sejarah dari masa ke masa. Perlunya peningkatan keterampilan berpikir historis ini bisa direalisasikan dengan pengembangan model-model pembelajaran sejarah yang dapat menunjang keterampilan tersebut. Setidaknya di dalam artikel ini bertujuan untuk mengulas tentang membentuk karakter bangsa melalui penguatan keterampilan berpikir historis yang dikembangkan melalui model-model pembelajaran yang dikemas dengan nuansa baru (dalam kurun waktu 5 tahun terakhir) di masa sekarang dalam pembelajaran sejarah di sekolah.
\end{abstract}

Kata Kunci: Membangun Karakter Bangsa, Keterampilan Berpikir Historis, Pembelajaran Sejarah

\section{PENDAHULUAN}

Bagi sebuah bangsa yang beradab, karakter merupakan hal yang sangat utama harus dimiliki dan dibangun bagi setiap generasinya. Penguatan nilai-nilai karakter bagi sebuah bangsa merupakan wacana yang besar diimpikan terwujud secara sempurna dalam menyongsong peradaban bangsa yang jauh lebih maju. Hal demikian juga berlaku bagi bangsa kita yaitu 
Indonesia. Indonesia yang menjadi Negara kaya akan budaya dan sejarah selalu memiliki elok rupawan. Kekayaan budaya dan sejarah yang dimiliki bangsa Indonesia membentuk begitu banyak nilai-nilai leluhur di setiap daerah dan juga secara nasional. Nilai-nilai leluhur masa lampau tersebut merupakan bagian dari karakter bangsa Indonesia. Seiring waktu berjalan dan masa yang terus berubah, dinamika pembentukan karakter bangsa harus terus digalakkan dalam upaya pencegahan lunturnya nilai-nilai karakter bangsa Indonesia di setiap generasinya.

Ketika berbicara tentang nilai-nilai leluhur masa lampau tentu tidak terlepas dari aspek sejarah. Aspek sejarah yang dimaksud dalam hal tersebut berkaitan dengan proses mewariskan nilai-nilai leluhur atau kearifan lokal melalui pembelajaran sejarah di sekolah. Diterangkan dalam Sirnayatin (2017:312) menurut Peraturan Menteri Pendidikan Nasional (Permendiknas) Nomor 22 Tahun 2006 tentang standar isi menegaskan bahwa pengetahuan masa lampau mengandung nilainilai kearifan yang dapat digunakan untuk melatih kecerdasan, membentuk sikap, watak dan kepribadian peserta didik. Untuk itu nilai-nilai sejarah harus dapat tercermin dalam pola prilaku nyata peserta didik.

Dalam penanaman karakter bangsa juga dikenal istilah pendidikan karakter. Dinyatakan dalam Undang-undang nomor 20 tahun 2003 tentang Sistem Pendidikan Nasional maka pendidikan budaya dan karakter bangsa diartikan sebagai proses internalisasi serta penghayatan nilainilai budaya dan karakter bangsa yang dilakukan peserta didik secara aktif dibawah bimbingan guru, kepala sekolah dan tenaga kependidikan serta diwujudkan dalam kehidupannya di kelas, sekolah, dan masyarakat (Hasan, 2012:84). Pelaksanaan pendidikan karakter diinternalisasikan dalam muatan kurikulum pembelajaran. Mata pelajaran sejarah hakikatnya memiliki peluang yang besar dalam menyukseskan pendidikan karakter bagi generasi bangsa di masa ini. Mata pelajaran Sejarah memiliki arti strategis dalam pembentukan watak dan peradaban bangsa yang bermartabat serta dalam pembentukan manusia Indonesia yang memiliki rasa kebangsaan dan cinta tanah air. Dengan karakter materi yang dinyatakan dalam Peraturan Mendiknas, pendidikan sejarah, baik sebagai bagian IPS mau pun sebagai mata pelajaran merupakan salah satu mata pelajaran yang memiliki potensi besar dalam mengembangkan pendidikan karakter (Hasan, 2012:87). Seperti yang sudah dijelaskan di atas bahwa nilai-nilai leluhur masa lampau dapat difungsikan sebagai jalan utama membangun karakter bangsa yang sejalan dengan perkembangan zaman. Bukanlah menjadi nilai kuno yang tidak dapat diimplementasikan saat ini, tetapi nilai-nilai leluhur merupakan warisan krusial para pendahulu setiap generasi bangsa. 
Mengajarkan nilai-nilai karakter bangsa kepada peserta didik dalam pembelajaran sejarah memerlukan keterampilan yang harus dibentuk oleh guru pada siswa yaitu keterampilan berpikir historis. Hal ini berkaitan dengan kemampuan siswa dalam memahami setiap nilai-nilai karakter bangsa yang terkonsep dalam ruang dan waktu masa lampau. Tentunya dalam membentuk keterampilan tersebut diperlukan penguasaan dan pemilihan model pembelajaran yang pas oleh guru sejarah. Sejarah menjadi aktual ketika diteliti dan dipelajari pada masa sekarang. Masalah

yang kerap kali terjadi pada saat pembelajaran sejarah secara umum berlangsung ialah pembelajaran sejarah yang hanya sebatas pengetahuan, suatu kemampuan berpikir tingkat rendah. Padahal mestinya lebih dikembangkan kemampuan tingkat berpikir lebih tinggi, seperti menganalisis atau bahkan sampai mengevaluasi. Mengevaluasi itu dalam proses pembelajaran termasuk atribut berpikir kritis yang disebut pemberian pertimbangan (Anis, 2021:3). Tantangan yang cukup besar dihadapi oleh seorang guru sejarah di mana harus benar-benar bisa mentransformasikan nilai-nilai dan makna dari setiap peristiwa sejarah kepada siswa. Penguatan keterampilan berpikir historis dapat dicanangkan dengan adanya berbagai macam pengembangan model pembelajaran sejarah yang mendukung baik yang benar-benar baru maupun model lama dengan kemasan baru. Berangkat dengan pentingnya membangun karakter bangsa yang dapat dicapai dengan adanya penguatan keterampilan berpikir historis dalam pembelajaran sejarah, maka artikel ini akan mengulas tentang pentingnya karakter bangsa dan upaya pembentukannya melalui keterampilan berpikir historis dalam pembelajaran sejarah.

\section{PEMBAHASAN}

\section{URGENSI MEMBANGUN KARAKTER BANGSA}

Era yang semakin mengglobal dengan adanya internalisasi nilai-nilai luar atau asing perlu disikapi sebagai alarm pengingat seluruh elemen bangsa dalam melindungi keberlangsungan karakter generasi bangsa Indonesia saat ini. Degradasi moral adalah satu di antara sekian banyaknya dampak dari lemahnya pembangunan karakter bangsa yang harusnya dimiliki oleh peserta didik. Membangun karakter bangsa membutuhkan waktu yang lama dan harus dilakukan secara berkesinambungan. Pemerintah kita, yang diwakili oleh Kementerian Pendidikan Nasional tiada henti-hentinya melakukan upaya-upaya untuk perbaikan kualitas pendidikan di Indonesia, namun belum semuanya berhasil, terutama menghasilkan insan Indonesia yang berkarakter. Salah satu upaya untuk mewujudkan pendidikan yang seperti di atas, para peserta didik (siswa dan 
mahasiswa) harus dibekali dengan pendidikan khusus yang membawa misi pokok dalam pembinaan karakter/akhlak mulia (Zaman, 2019:18).

Karakter bangsa adalah modal dasar membangun peradaban tingkat tinggi, masyarakat yang memiliki sifat jujur, mandiri, bekerja sama, patuh pada peraturan, bisa dipercaya, tangguh dan memiliki etos kerja tinggi, akan menghasilkan sistem kehidupan sosial yang teratur dan baik (Hasibuan, 2012:63). Kehidupan social yang teratur dan baik merupakan dambaan dan harapan bagi sebuah bangsa yang ingin maju. Penanaman nilai-nlai karakter bangsa sudah harus dimulai sejak sedini mungkin dengan dimulai dari lingkungan keluarga. Dalam lingkungan sekolah, karakter bangsa dimuat dalam pembelajaran yang dilaksanakan. Peran guru tentunya begitu krusial dalam merancang internalisasi nilai-nilai karakter di dalam mata pelajaran yang akan diajarkan. Pengajaran nilai-nilai karakter bangsa menjadi tanggung jawab seluruh elemen dalam dunia pendidikan.

\section{PENGUATAN KETERAMPILAN BERPIKIR HISTORIS MELALUI MODEL PEMBELAJARAN SEJARAH}

Seperti yang sudah diterangkan sebelumnya pada bagian artikel ini, pembelajaran sejarah hakikatnya memiliki keterkaitan yang kuat dengan pendidikan karakter sebagai bagian dari upaya membangun karakter bangsa dari masa ke masa. Menurut Hasan dalam Anis (2014:192-193), bila dihubungkan antara pendidikan sejarah dengan pendidikan karakter, maka dalam pendidikan sejarah terdapat; mengembangkan kemampuan berpikir kritis, berpikir kreatif, mengembangkan sikap kepahlawanan dan kepemimpinan, mengembangkan semangat kebangsaan, mengembangkan kepedulian sosial, mengembangkan kemampuan berkomunikasi, dan mengembangkan kemampuan mencari, mengolah, mengemas dan mengomunikasikan informasi. Pengajaran karakter bangsa melalui pendidikan sejarah bukanlah hal yang baru saja muncul, persoalan tersebut sudah menjadi perbincangan lawas yang masih terus dikembangkan dari zaman ke zaman. Mulai dari perancangan strategi pembelajaran yang mencakup penggunaan model pembelajaran yang diperuntukkan bagi siswa.

Pengajaran nilai-nilai karakter bangsa tidak bisa diabaikan dari keterampilan berpikir historis yang harus dimiliki siswa. Penguatan keterampilan berpikir historis bagi siswa dapat 
dicapai dengan kemampuan guru yang mampu memahami kebutuhan kelas dan setiap siswa dalam pembelajaran sejarah. Keterampilan berpikir historis ini sebenarnya berpusat pada kemampuan siswa dalam mencapai tingkat pemahaman tinggi terkait hakikat dari belajar sejarah. Dalam hal ini keterampilan tersebut harus dibentuk dengan kiat-kiat strategis. Membangun kemampuan berpikir historis memerlukan sebuah model pembelajaran. Oleh karena itu, Model Pembelajaran Berpikir Historis (MPBH) dibangun agar siswa memiliki keterampilan dalam menghubungkan peristiwa masa kini dengan fenomena sejarah (Anis, 2021:90). Model pembelajaran tersebut muncul dari adanya problematika pembelajaran sejarah yang bersifat konvensional. Pembelajaran konvensional tersebut cenderung hanya menekankan pada aspek kognitif berupa hafalan. Umumnya siswa yang berpartisipasi dalam pembelajaran sejarah konvensional akan dipenuhi dengan stigma hafalan terkait nama tokoh, tanggal kejadian sebuah peristiwa dan informasi sempit lainnya. Padahal dalam mengajarkan sejarah ada yang jauh lebih penting diterima oleh siswa yaitu nilai dan makna dari peristiwa masa lampau yang bisa dikaitkan dengan masa kini untuk menyongsong masa yang akan datang. Penerapan Model Pembelajaran Berpikir Historis bukan pula hal yang baru dijumpai dalam pembelajaran sejarah. MPBH ini merupakan model pembelajaran lawas yang dikemas dengan nuansa baru kekinian. Siswa lebih dieksplor pengetahuan nya dengan berpikir secara kristis dan historis. Ide MPBH dirasa mampu mendekonstruksi sebuah pemahaman tentang studi sejarah dari perspektif masa kini. MPBH tentunya berbeda dengan konvensional pembelajaran sejarah yang didominasi oleh hafalan. Perbedaan itu ditandai dengan memudahkan siswa untuk memperoleh informasi sejarah, kritis, dan membantu siswa menjadi terampil ikut berpartisipasi dalam MPBH (Anis, 2021:92).

\section{SIMPULAN}

Mengajarkan sejarah kepada generasi bangsa di era yang semakin modern ini harus mampu sejalan dengan upaya membangun karakter bangsa. Karakter bangsa diperlukan dalam hal melindungi setiap insan bangsa yang memiliki watak dan kepribadian sesuai dengan nilai leluhur bangsa pendahulu. Pembelajaran sejarah memiliki peran yang cukup besar dalam upaya membangun nilai karakter bangsa. Karena dalam pembelajaran sejarah terintegrasi nilai dan makna warisan dan pembelajaran para leluhur bangsa. Dalam mengajarkan sejarah, diperlukan kemampuan guru untuk menciptakan kelas yang mengakomodasi minat dan kebutuhan siswa 
dalam mengikuti pembelajaran sejarah. Sudah seharusnya model pembelajaran sejarah yang bersifat konvensional ditinggalkan dan dikemas dengan model pembelajaran baru. Hal ini bertujuan agar pembelajaran sejarah yang dihadapi siswa tidak dinilai sebagai suatu hal yang kuno dan membosankan. Terlebih lagi dalam pencapaian tujuan pembelajaarn sejarah dimiliki sebuah keterampilan krusial yaitu keterampilan berpikir historis. Dari berbagai literature yang ada, model pembelajaran sejarah yang jauh lebih inovatif dengan mudah ditemui. Salah satunya adalah Model Pembelajaran Berpikir Historis (MPBH). Model pembelajaran tersebut menekankan pada partisipasi siswa yang lebih aktif dalam pemeblajaran sejarah guna melatih siswa untuk berpikir secara kritis dan mampu memiliki persepktifnya sendiri terkait fenomena sejarah pada masa lampau kaitannya dengan masa kini.

\section{DAFTAR PUSTAKA}

Anis, M. Z. A., Putro, H. P. N., Susanto, H., \& Hastuti, K. P. (2020). Historical Thinking Model in Achieving Cognitive Dimension of Indonesian History Learning. PalArch's Journal of Archaeology of Egypt/Egyptology, 17(7), 7894-7906.

Anis, M. Z. A., Susanto, H., \& Mardiani, F. (2021, February). Analysis of the Effectiveness of MPBH: The Mains of Mandai as a Saving Food in Banjarmasin Community. In The 2nd International Conference on Social Sciences Education (ICSSE 2020) (pp. 89-94). Atlantis Press.

Anis, M. Zaenal Arifin. (2014). Pendidikan Sejarah Berbasis Pendidikan Karakter. FKIP UNLAM PRESS: Penerbit Niaga Sarana Mandiri.

Hasan, S. H. (2012). Pendidikan sejarah untuk memperkuat pendidikan karakter. Paramita: Historical Studies Journal, 22(1).

Hasibuan, M. (2014). Makna dan urgensi pendidikan karakter. FITRAH: Jurnal Kajian Ilmu-ilmu Keislaman, 8(1), 59-76.

Mardiani, M. Z. A. A. F. (2021). Memperkuat Identitas Nasional Melalui Model Pembelajaran Berpikir Historis (Mpbh): Antara Nyata Atau Sebuah Asa?. In Prosiding Seminar Nasional Lingkungan Lahan Basah (Vol. 6, No. 3).

Sirnayatin, T. A. (2017). Membangun Karakter Bangsa Melalui Pembelajaran Sejarah. SAP (Susunan Artikel Pendidikan), 1(3).

Zaman, B. (2019). Urgensi Pendidikan Karakter yang sesuai dengan Falsafah Bangsa Indonesia. Al Ghazali, 2(1), 16-31. 